\title{
Assessment of Microbiological quality by coliform estimation in drinking water sources of Mathura region
}

\author{
Udit Jain*, Basanti Bist ${ }^{1}$ and D.D. Lalwani \\ Department of Veterinary Public Health, Pt.Deen Dayal Uphadhyaya Pashuchikitsa Vigyan Vishwavidyalaya Evam Gau \\ Anusandhan Sansthan (DUVASU), Mathura-281001(UP)
}

A total of 100 water samples from various sources of drinking water namely municipal tap water $(n=20)$, packaged drinking water of different brands $(n=20)$, underground water (hand pump and submersible water) $(n=40)$ and stored water (Public places like hospitals, railway station \& bus stand etc.) $(\mathrm{n}=20)$ were collected from different areas of Mathura, Uttar Pradesh and estimation of coliform bacilli was carried out in a water supply by multiple tube technique. Of 100 water samples, 20 had no coliforms, whereas remaining 80 (80\%) had coliforms ranging from 1 to $>1600 / 100 \mathrm{ml}$ of water. Most of the positive samples had coliform count ranging between 1-10 (21\%), < $50(18 \%)$ and $>1600(28 \%)$. Only $13(13 \%)$ of the samples had coliform count ranging between 50-1600. The poor microbial quality of drinking water samples, as revealed in this study is a matter of public health concern.

Keywords: Assessment, Microbiological quality, Drinking water, Coliform, Mathura

\section{INTRODUCTION:}

The importance of good drinking water in maintaining health was recognised early in human history, with water storage and treatment mentioned in historical records dating back to at least several hundreds years B.C.. Pathogens which are likely to be spread through water are members of Enterobacteriaceae and Vibrionaceae. But some other bacteria are Salmonella spp., E.coli, Vibrio cholerae, Aeromonas spp. are also transmitted through water (Gugnani, 1999). Microbiological indicators have been used to determine or indicate the safety of water for drinking. Bacteria of coliform group are considered the primary indicators of faecal contamination and most frequently applied. (Raina et al., 1999). Estimation of coliforms helps in determining the faecal contamination of water and probably the presence of intestinal pathogens.

\section{MATERIALS AND METHODS:}

A total of 100 water samples from various sources of drinking water namely municipal tap water $(n=20)$, packaged drinking water of different brands $(n=20)$, underground water (hand pump \& submersible water) $(n=40)$ and stored water (Public places like hospitals, railway station \& bus stand etc.) $(\mathrm{n}=20)$ were collected from different areas of Mathura, Uttar Pradesh and processing for coliform estimation was done by method of Cruickshank et al., 1975.

\section{RESULTS AND DISCUSSION:}

Of 100 water samples from different drinking water sources, the 20 samples were found negative for total coliforms (MPN/100 ml), whereas remaining 80(80\%) had coliforms ranging from 1 to $\geq 1600 / 100 \mathrm{ml}$ of water (table-1). Most of the positive samples had coliform count ranging between 1-10(21\%), <50 (18\%) and >1600(28\%). Only 13(13\%) of the samples had coliforms count ranging between 50-1600. Source wise results showed that in tap water source, out of 20, only 6(30\%) did not reveal coliforms. In stored water, 18(90\%) of 20 samples had coliform count of $>1600 / 100 \mathrm{ml}$ water and only one sample was negative for coliforms. In stored water $20 \%$ samples were found negative for total coliforms and $9(22.5 \%)$ had coliform count of $>1600 / 100 \mathrm{ml}$. Only packaged drinking water source was found good source having $12(60 \%)$ of 20 samples negative for total coliforms. Similar findings for different drinking water sources like unsatisfactory microbiological quality 
IOSR Journal of Pharmacy

Vol. 2, Issue 3, May-June, 2012, pp.500-503

for drinking water was reported by Lippy and Waltrip, 1984, Craun, 1985, Rahman et al., 1996, for packaged drinking water by Hunter and Burge, 1987, Ogan, 1992, Dainik Jagran News Paper, 2002, in stored water sources (water coolers) 18 of 120 samples (15\%) was observed by Joshi ,N., 2007. Water samples was also found unsatisfactory quality in all sources similar to present study by Abraha, 2000.

Table-.1 Total coliforms (MPN/100ml) in drinking water samples from different sources (\%).

\begin{tabular}{|c|c|c|l|c|c|c|c|c|}
\hline S.No. & Sources & $<\mathbf{1}(\mathbf{0})$ & $\mathbf{1 - 1 0}$ & $\mathbf{> 1 0}-<\mathbf{5 0}$ & $\mathbf{5 0 - 1 0 0}$ & $\mathbf{1 0 0 - 5 5 0}$ & $\mathbf{5 5 5 - 1 6 0 0}$ & $>\mathbf{1 6 0 0}(\mathbf{1 8 0 0})$ \\
\hline 1. & $\begin{array}{c}\text { Tap water } \\
(\mathrm{n}=20)\end{array}$ & $6(30)$ & $4(20)$ & $6(30)$ & $1(5)$ & $1(5)$ & $1(5)$ & $1(5)$ \\
\hline 2. & $\begin{array}{c}\text { Stored water } \\
(\mathrm{n}=20)\end{array}$ & $1(5)$ & - & $1(5)$ & - & - & - & $18(90)$ \\
\hline 3. & $\begin{array}{c}\text { Underground water } \\
(\mathrm{n}=40)\end{array}$ & $8(20)$ & $10(25)$ & $4(10)$ & $1(2.5)$ & $4(10)$ & $4(10)$ & $9(22.5)$ \\
\hline 4. & $\begin{array}{c}\text { Packaged water } \\
(\mathrm{n}=20)\end{array}$ & $5(25)$ & $7(35)$ & $7(35)$ & $1(5)$ & - & - & - \\
\hline & $\begin{array}{c}\text { Total } \\
(\mathbf{n = 1 0 0})\end{array}$ & $\mathbf{2 0}(\mathbf{2 0})$ & $\mathbf{2 1}(\mathbf{2 1})$ & $\mathbf{1 8 ( 1 8 )}$ & $\mathbf{3 ( 3 )}$ & $\mathbf{5}(\mathbf{5})$ & $\mathbf{5 ( 5 )}$ & $\mathbf{2 8}(\mathbf{2 8})$ \\
\hline
\end{tabular}

Figures in parenthesis indicate percentage

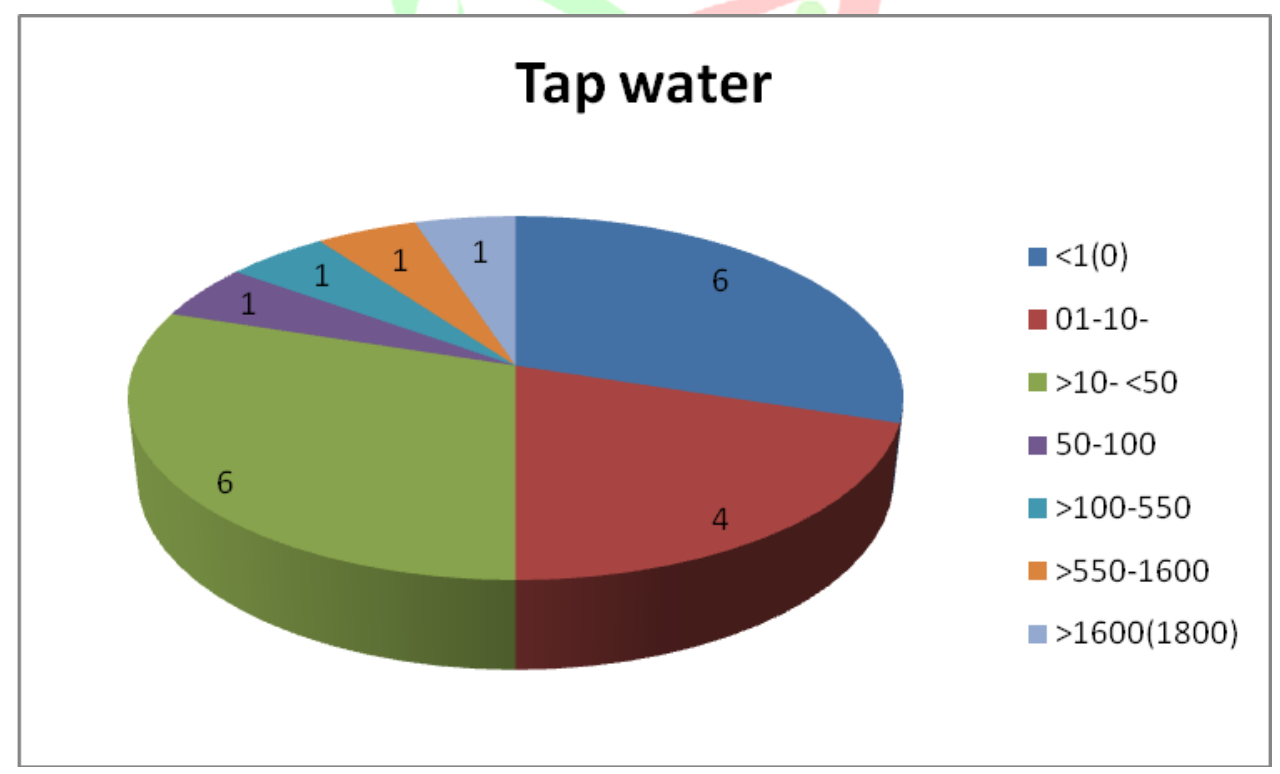

Fig1: Pie diagram showing number of tap water samples comes under different ranges of total coliforms. 


\section{Stored water}

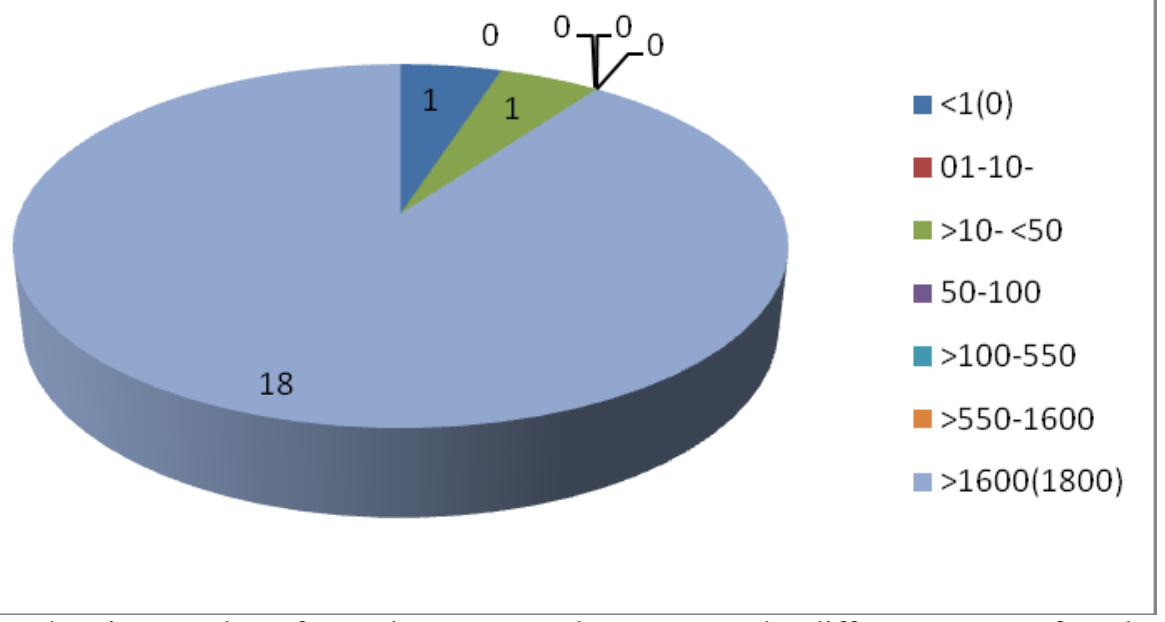

Fig2: Pie diagram showing number of stored water samples comes under different ranges of total coliforms.

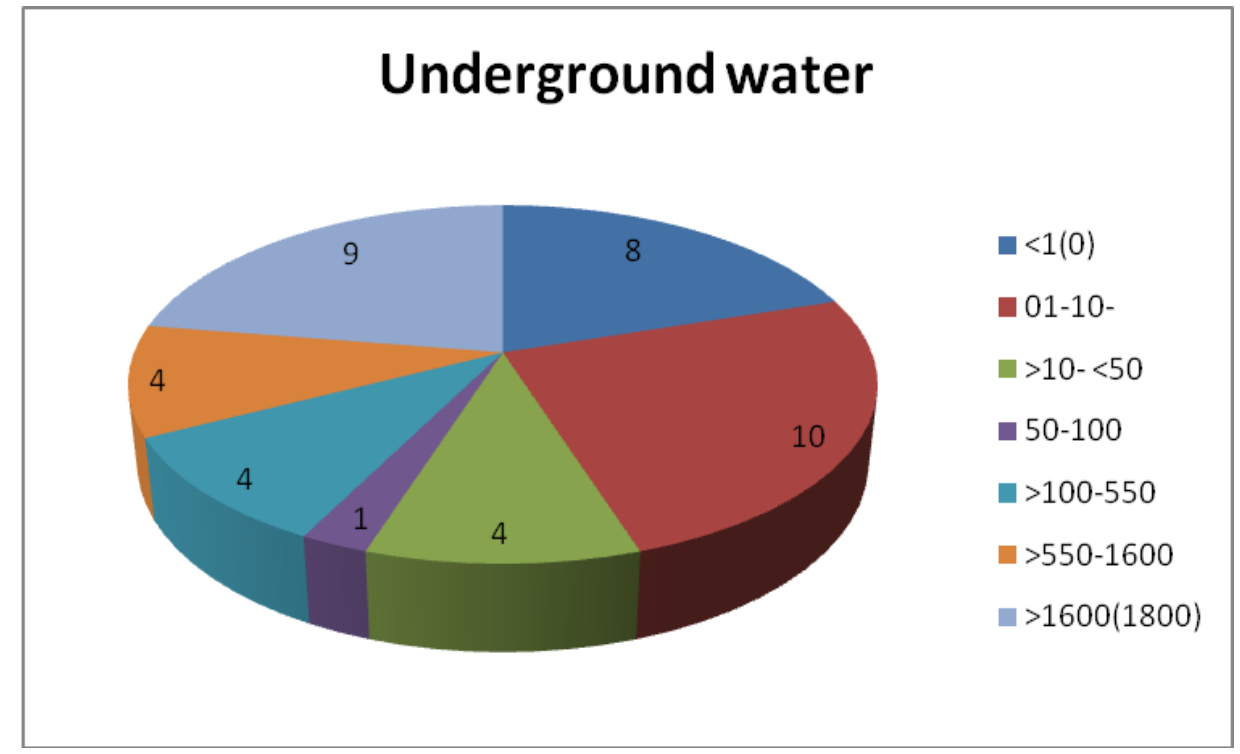

Fig3: Pie diagram showing number of underground water samples comes under different ranges of total coliforms.

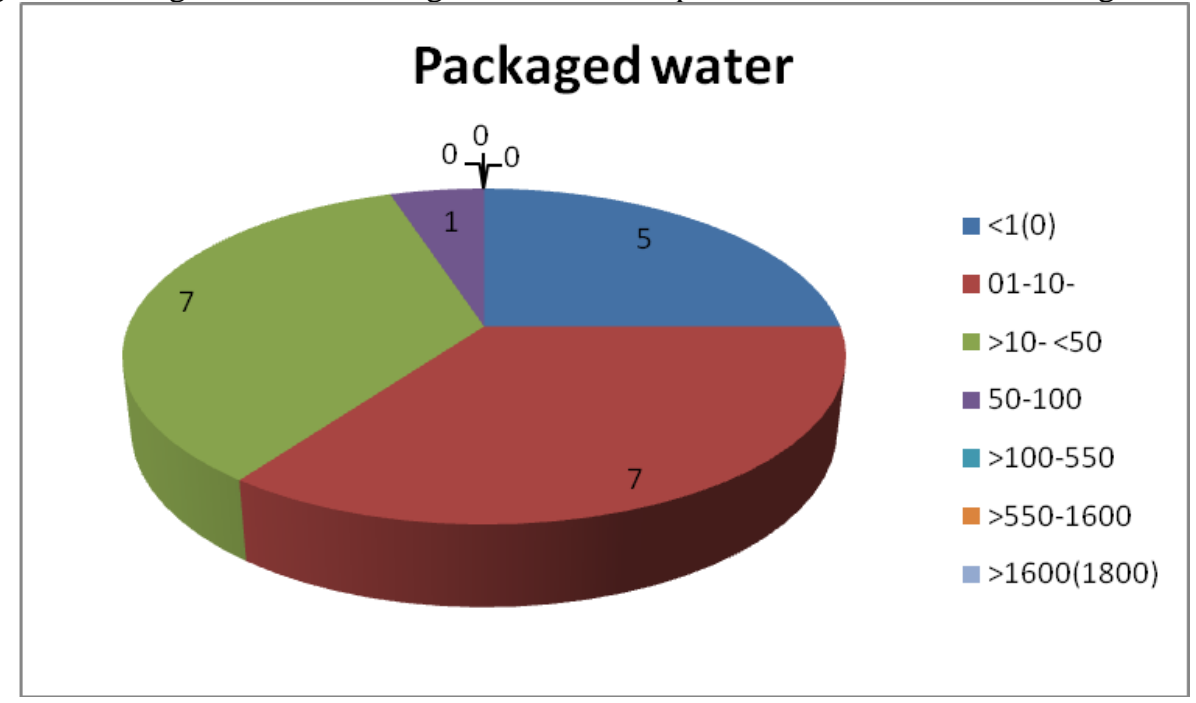

Fig4: Pie diagram showing number of packaged water samples comes under different ranges of total coliforms. 
IOSR Journal of Pharmacy

Vol. 2, Issue 3, May-June, 2012, pp.500-503

\section{CONCLUSIONS:}

The poor microbial quality of drinking water samples, as revealed in this study viz. high percentage of coliforms (95.0\% in stored water) in different drinking water sources, is a matter of public health concern. Higher presence of coliforms in stored water indicates poor handling and unhygienic conditions.

\section{ACKNOWLEDGEMENT:}

Authors are very much thankful to Hon'ble Vice Chancellor, DUVASU, Mathura and Dean, College of Veterinary Science and Animal Husbandry, Mathura for providing necessary facilities in the department of Veterinary Public Health, College of Veterinary Science and Animal Husbandry, DUVASU, Mathura.

\section{REFERENCES:}

[1]. Abraha Gassesew (2000). Assessment of microbiological quality of drinking water in Bareilly. M.V.Sc. thesis IVRI, Izatnagar.

[2]. Crown, G.F. (1985). An overview of statistics on acute and chronic water contamination problems. In:Fourth domestic water quality symposium. Point of use treatment and its implications. Water quality association. Lisle, IL, pp.5-15.

[3]. $\quad$ Cruickshank, R.; Duguid, J.P.; Marmion, B.Pm and Swain, R.H.A. (1975). Medical Microbiology. Twelfth Ed. Churchill, Livingstone, London.

[4]. Dainik JagranNewspaper (2002). Savadhan:Thelion mein bik raha hai maut ka samaan. Published in Mathura sammachar page no. 2 on $22^{\text {nd }}$ March, 2002.

[5]. Gugnani, H.C. (1999). Some emerging food and water borne pathogens. J.Commun.Dis. 31:65-72.

[6]. Hunter, P.R. and Burge, S.H. (1987). The bacteriological quality of bottled natural mineral waters. Epidem. Inf. 99:439-443.

[7]. Joshi Namita (2007). Sanitary analysis of drinking water in and around Pantnagar Campus. Published in National Symposium (IAVPHS 2007), 254

[8]. Lippy, E.C. and Waltrip, S.C. (1984). Waterborne disease outbreaks. 1946-1980. A thirty-five-year perspective. J.Am.water works Assoc. 76:60-67

[9]. Ogan, M.T. (1992). Microbiological quality of bottled water sold in retail outlets in Nigeria. J.Appl. Bacteriol. 73:175-181.

[10]. Raina, P.S., Pollaria, F.L., Teare, G.F., Goss, M.J., Barry, D.A.J. and Wilson, J.B. (1999). The relationship between E.coli indicator bacteria in well water and gastrointestinal illness in rural families. Canadian $J$. Pub. Health. 90:172-175.

[11]. Rahman A., Lee, H.K. and Khan, M.A. (1996). Domestic water contamination in rapidly growing mega cities of Asia: Case of Karanchi, Pakistan. Environ. Monitoring Assessment. 44:339-360.

[12]. Cruickshank, R.; Duguid, J.P.; Marmion, B.Pm and Swain, R.H.A.(1975). Medical Microbiology. Twelfth Ed. Churchill, Livingstone, London.

[13]. Bergey's Manual of Determinative Bacteriology (1994). Williams and Wilkins, Baltimore, Hong Kong, London, Munich. 